Realizing stretch goals via exploratory bricolage: The case of Chinese entrepreneurial firms Shihao Zhou, Peter Ping Li, Monsol Zhengyin Yang

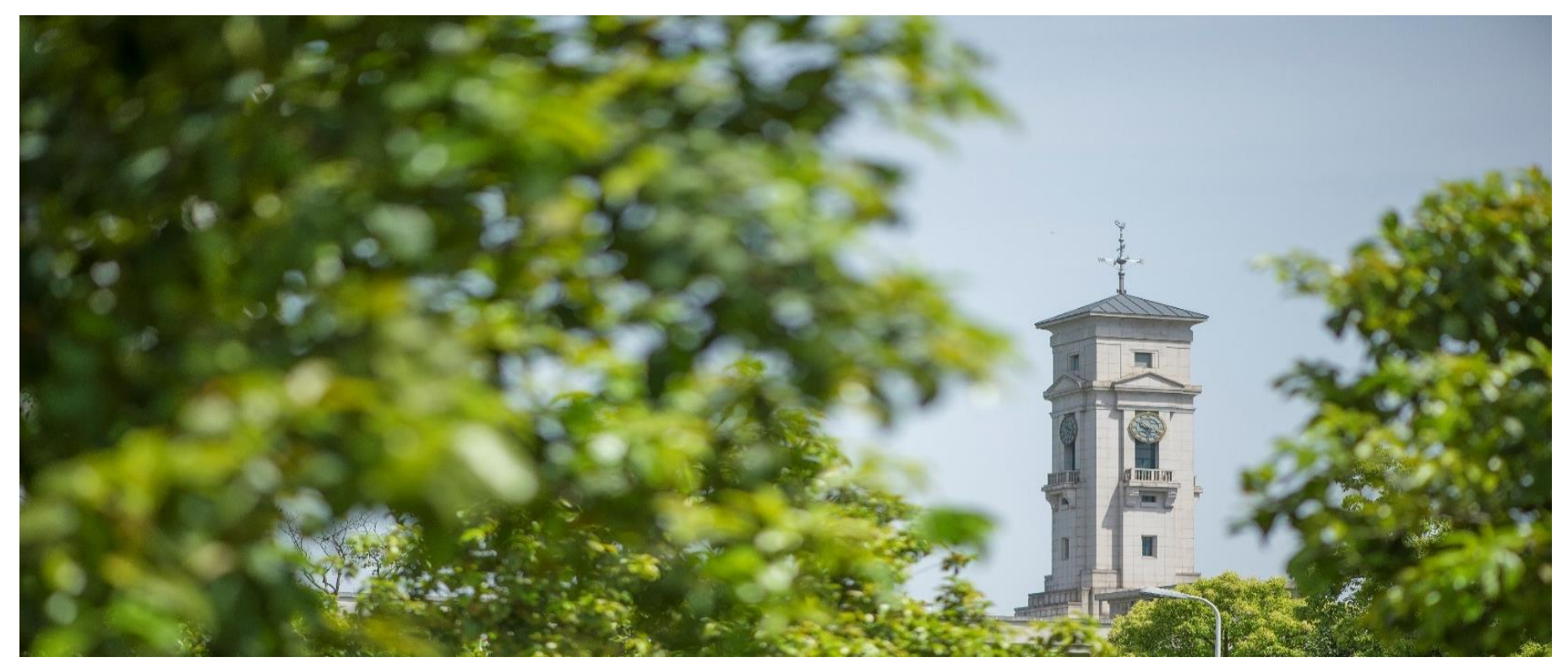


University of Nottingham Ningbo China, 199 Taikang East Road, Ningbo, 315100, Zhejiang, China.

First published 2019

This work is made available under the terms of the Creative Commons Attribution 4.0 International License:

http://creativecommons.org/licenses/by/4.0

The work is licenced to the University of Nottingham Ningbo China under the Global University Publication Licence:

https://www.nottingham.edu.cn/en/library/documents/research/global -university-publications-licence-2.0.pdf 


\title{
Realizing Stretch Goals via Exploratory Bricolage:
}

\section{The Case of Chinese Entrepreneurial Firms}

\author{
Shihao Zhou \\ Nanjing University, Nanjing, China \\ Peter Ping Li \\ University of Nottingham, Ningbo, China; \\ Center for Creative Leadership, Greater China Region \\ Copenhagen Business School, Denmark \\ Monsol Zhengyin Yang \\ University of Nottingham, Ningbo, China
}

A fundamental paradox of entrepreneurship is the tension between a passionate entrepreneur's stretch goal, i.e. goals that are seemingly impossible given his or her current resources or capabilities, and the serious lack of access to required resources or capabilities. On one hand, a firm's performance is argued to be largely shaped by the valuable, rare, inimitable, and non-substitutable (VRIN) resources it holds (Barney, 1991), and some organizational learning scholars posit that conducting explorative learning for a stretch goal is likely to be harmful for firms facing severe resource constraints (Sitkin, See, Miller, Lawless \& Carton, 2011). It is self-evident that pursuing stretch goals entails enormous challenges and expenses for firms, especially vulnerable ones with limited resources. On the other hand, in the business world, many well-known entrepreneurs set a stretch goal when their firms are in a severe resource deficiency, and later on many of them come up with radical innovations and achieve extraordinary performance far above market expectations. The above two views constitute one of the most salient and challenging paradoxes for both scholars and practitioners. We need to go beyond the extant literature so as to effectively explain this specific paradox, especially about how an entrepreneurial firm confronting severe resource 
constraints can achieve its stretch goal with extraordinary performance.

In particular, the emergence of almost all successful firms in China (e.g., Huawei, Haier, Alibaba, and Tencent, among others) at the initial stages and even the later stages of firm growth, all under the similar conditions of serious competitive disadvantages due to the severe lack of VRIN resources. Those firms all started nearly from nothing with no original technology and technical accumulation, no venture capital, no power background, and even no capable talents. For instance, Ren Zhengfei, the CEO and founder of Huawei once advocated that Huawei will ultimately be one of the third top companies in information and communication industry all over the world in an early stage. Tencent was nearly sold to Sohu in 2000 at a price of 1 million RMB when the founder of Tencent Pony Ma thought he could not sustain the company any longer; the current market value of his company overpasses 500 billion US dollars. Their great stretch goals and the absence of VRIN resources are in stark contrast. We can focus on the specific cases of Chinese firms to explain how such a paradox can be effectively managed or balanced.

Specifically, we argue that the notion of bricolage can be evoked to resolve the tension between having a stretch goal and lacking required resources. In terms of "making do by applying combinations of the resources at hand to new problems and opportunities" (Baker \& Nelson, 2005: 333), bricolage is perhaps the most relevant perspective to explain the special entrepreneurial behaviors in resource-scarce contexts (Senyard, Baker, Steffens \& Davidsson, 2014; Garud \& Karnøe, 2003; Guo, Su \& Ahlstrom, 2015; Welter, Mauer \& Wuebker, 2016). This perspective posits that, in order to resolve the problem of resource constraints, a firm needs to engage in bricolage by challenging the extant institutional assumptions as well as 
reusing existing resources in new ways (Baker \& Nelson, 2005). In particular, bricolage can provide a viable venue for firms in emerging markets such as China to grow under resource constraints (Gurca \& Ravishankar, 2016; Wu, Liu \& Zhang, 2016). From the perspective of bricolage, innovation is explicitly and directly viewed as a solution to the problem of resource constraints. However, the extant research on bricolage is limited in framing it as leading to frugal innovations to the extent that, with substandard resources at hand, some entrepreneurs can only create substandard products that serve customers who cannot afford at standard prices (Senyard et al., 2014). Further, bricolage is commonly identified as a pure exploitative search with an emphasis on only short-term or near-term and path-dependent goals (Baker \& Nelson, 2005) due to its emphasis on "make-do", which means to employ whatever resources available. Finally, there is almost a complete blank in terms of literature on the process of bricolage by the firms in the emerging economies (Senyard, Baker \& Davidsson, 2009; Salunke, Weerawardena \& McColl-Kennedy 2013).

Hence, the extant perspective of bricolage seems to imply that bricoleurs can only gain a competitive parity or develop temporary advantages (Baker \& Nelson, 2005; Fisher, 2012; Senyard et al., 2014), so it fails to explain why and how some bricoleurs could deliver an extraordinary performance under resource constraints. To fill the above gap in the literature, we seek to effectively explain the specific paradox about stretch goal and resource constraints in terms of how an entrepreneurial firm with severe resource constraints can achieve its stretch goal for extraordinary performance.

Specifically, we argue that the extant research on bricolage focuses too narrowly on what we call exploitative bricolage as one of multiple mechanisms (i.e., making-do with whatever 
resources at hand, similar to the approach of effectuation in terms of pursuing only any goal achievable with available resources, Sarasvathy, 2001, 2008), so we intend to develop a novel view by identifying the other mechanism of what we call exploratory bricolage (i.e., creating radical innovations or other extraordinary outcomes out of not only ordinary resources, but also even seemingly valueless "non-resources"). In particular, we posit that the key antecedent to exploratory bricolage is stretch goal with its unique role in driving entrepreneurs to engage in exploratory bricolage as necessary and salient (cf. Sitkin et al., 2011). We argue that exploratory bricolage can better explain the perspective about "creating something from nothing". We propose an integrative framework of entrepreneurial bricolage with exploratory bricolage as the primary mechanism to explore novel solutions of converting or transforming ordinary resources and/or seemingly valueless non-resources at hand into radical outcomes to match the stretch goal.

We analyze three cases to illustrate and enrich the notion of explorative bricolage and discuss the achievement of stretch goals by entrepreneurial firms using substandard resource at hand. In particular, we choose cases from China, where we see several entrepreneurial firms facing severe resource constraints at the beginning have become global power players through a series of bricolage-driven innovations. Specifically, we discuss the three cases of Yuanjia Village, ZBOM Cabinets Co., and Huawei.

This chapter aims to explore and explain why those Chinese firms with unprivileged resources have managed to obtain great success via theoretical argument and case analysis. Particularly, we focus on the how question, i.e., how have they done that? And what are the core mechanisms and processes? We identify the bricolage pattern with both theoretical and 
practical implications for both scholars and practitioners. Our research contributes to the organization (Terjesen \& Patel, 2017) and entrepreneurship (Fisher, 2012; Welter et al., 2016) literatures by explaining how entrepreneurs can achieve seemingly impossible success via rather radical innovation based on local search.

\section{Theoretical Background}

\section{A. Stretch Goal}

We argue that, to better understand the unique pattern of innovation by late-coming firms in China, it is salient to study the role or effect of firm-specific stretch goal. Stretch goal is defined as a goal that is extremely difficult and seemingly impossible to achieve given the available resources and capabilities (Gary, Yang, Yetton, \& Sterman, 2017; Locke \& Latham, 2013; Sitkin et al., 2011). Having a stretch goal is critical because it encourages organizations to push the envelope of available resources so as to stimulate innovations within each firm. However, Sitkin et al. (2011) argue that stretch goals can only be achieved by firms with sufficient resources; therefore, pursuing stretch goals under the condition of resource constraints may impede the satisfactory performance of most, if not all, firms, and accordingly, create discomfort, stress, and rigidity at both individual and collective levels. Similarly, Gary et al. (2017) find that having a stretch goals does not help most individuals or organizations achieve a better performance.

Achieving competitive advantages in terms of innovativeness for late-coming firms in emerging economies can be regarded as a typical stretch goal (Lee \& Lim, 2001; Miao, Song, Lee, \& Jin, 2018). For example, for a Chinese late-coming software company, it will be extremely difficult for the company to challenge the dominant position of Microsoft in operating systems. According to Sitkin et al. (2011), pursuing a stretch goal under resource 
constraints will impede the typical growth of late-coming firms. However, as known to many, Jack Ma had set the ideal goal for Alibaba to be the greatest IT company on earth since its early days, but this was seemingly impossible for a new firm given its desperate need of resources. This stretch goal has made Alibaba a business leader in the world, which forces us to reconsider the hidden links between available resource, stretch goal, and innovative outcome. Hence, we need to think more deeply about the unique role or effect of bricolage, especially its more creative or exploratory version in contrast to its less creative or exploitative version, as the most relevant means or mechanism to convert or transform available resources into innovative outcomes via the facilitating effect of stretch goals.

Prior literature also indicates that although having a stretch goal may not improve performance generally, the stretch goal can potentially stimulate creativity and innovation (Katila \& Shane, 2005; Miron-Spektor \& Beenen, 2015). In an individual-level study, Miron-Spektor and Beenen (2015) find that when people who have a specific goal in learning are more likely to explore new knowledge domains, making these people come up with novel ideas. Katila and Shane (2005) examines the relationship between lack of resources and firm innovation. They find that lacking resources may encourage the firm to innovate. These studies imply that exploration and innovation could be an effective way of achieving stretch goals.

\section{B. Explorative Bricolage}

Bricolage has been brought into entrepreneurship and innovation research since the early 2000s (Baker, Miner \& Eesley, 2003; Baker \& Nelson, 2005). Based on this concept, when entrepreneurs are facing resource constraints, they could "make do by applying combinations of the resources at hand to new problems and opportunities" (Baker \& Nelson, 2005: 333). 
The insight provided by the notion of bricolage is that entrepreneurs may successfully achieve goals under the condition of resources constraints, and the way to achieve that is to test and challenge existing institutional assumptions (e.g., institutional logics, formal rules, informal norms, dominant logics, prevailing business models, etc.) so as to use ordinary or even seemingly valueless non-resources in novel ways (Baker \& Nelson, 2005; Garud \& Karnøe, 2003).

The concept of bricolage provides many useful pieces of advice for entrepreneurs to survive under resources constraints while the problem of resources constraints is one of the impeding factors for late-coming start-ups, especially in the emerging economies (Miao et al., 2018). This idea has shaken the position of two theories that hold the view that early-moving firms have better or more advanced capabilities for innovation. First, bricolage challenges the research-based view that the firm-specific competitive advantages are rooted in the ownership of VRIN resources (Barney, 1991, 2001). In terms of innovation, the resource-based view indicates that innovation must be based on the possession of corresponding resources such as advanced technologies, R\&D stock and R\&D experiences (Terziovski, 2010). However, the concept of bricolage indicates that organizations can turn subnormal resources, or even seemingly valueless non-resources, into VRIN resources for competitive advantages so that there is no absolute need for the prior possession of extraordinary resources as a required precondition.

Second, the concept of bricolage also challenges the view of organizational search for innovation and entrepreneurship. Based upon the view of organizational search, innovation and entrepreneurial opportunities can be detected through knowledge search (Kaish \& Gilad, 
1991; Levinthal \& March, 1993). Scholars of organizational search differentiate local search from nonlocal search, with the former involving the search for knowledge near their current knowledge domains, and the latter involving the search for knowledge in distant domains (Rosenkopf \& Almeida, 2003; Rosenkopf \& Nerkar, 2001). In the traditional view of organizational search, organizations focus on familiar and easily accessible resources in local search, which often generates incremental and exploitative innovations; in contrast, organizations focus on long-term variables, venture into new fields, and discover novel solutions in nonlocal search, which often generates radical and explorative innovations (Rosenkopf \& Nerkar, 2001). However, the concept of bricolage indicates that some radical innovations can derive from local, yet explorative, search. In fact, recent innovation studies show that, because local search brings a deep understanding of the relevant institutions, innovators are more likely to modify the underlying institutional logics so as to achieve truly radical innovations via engaging in local, rather than nonlocal, search (Jung \& Lee, 2016; Kaplan \& Vakili, 2015; Mastrogiorgio \& Gilsing, 2016).

However, the extant research on bricolage is limited in framing it as leading to frugal innovations to the extent that, with substandard resources at hand, some entrepreneurs can only create substandard products that serve customers who cannot afford at standard prices (Senyard et al., 2014). Furthermore, because bricolage emphasizes "make-do" with resources at hand, it is often viewed as a pure exploitative search with an emphasis on only short-term, or near-term and path-dependent, goals (Baker \& Nelson, 2005). Last, little is known about the process of bricolage by the firms in the context of emerging economies (Senyard et al., 2014; Salunke et al., 2013). In other words, the extant perspective of bricolage seems to 
imply that bricoleurs can only gain a competitive parity or develop temporary advantages (Baker \& Nelson, 2005; Fisher, 2012; Senyard et al., 2014), so it fails to explain why and how some bricoleurs could deliver an extraordinary performance under resource constraints. To differentiate our approach to bricolage as radically creative in contrast to the extant notion of bricolage as a simple "make-do with resources at hand", we frame the radical creative type as exploratory bricolage, while the typical type as exploitative bricolage. Figure 1.1 demonstrates the overall pattern of exploratory bricolage.

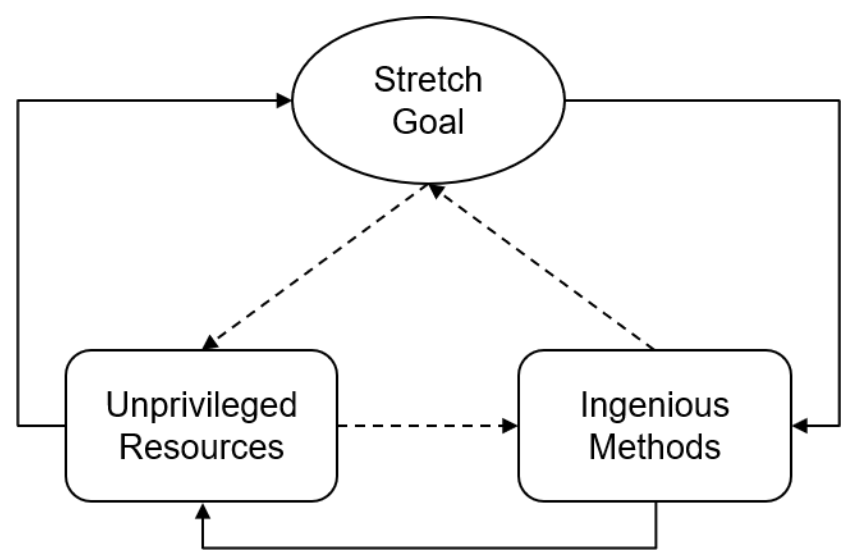

Figure 1.1: The Overall Pattern of Exploratory Bricolage

\section{The Interplay between Stretch Goal and Exploratory Bricolage}

Combining the interplay between exploratory bricolage and stretch goal for innovation, we argue that firms could achieve a stretch goal by engaging bricolage in a radically creative manner. This type of bricolage is the key to radical innovation for late-coming firms in such emerging economies as China. However, while the extant research on bricolage regards stretch goals for late-coming firms as seemingly impossible (Baker \& Nelson, 2005; Senyard et al., 2014), the extant research on stretch goals fails to pay attention to the potential effect of bricolage (Sitkin et al., 2011). In this sense, integrating the two would provide us with more salient insights, especially concerning the interplay between the two factors. 
The impossibility of stretch goals derives from the old norms within mature firms, so only by challenging the domain technologies, business models, and operating processes can it achieve radical or disruptive innovations (Wu et al., 2010). In contrast, given the resource constraints of late-coming firms, they must focus on improving the effectiveness of applying currently available or easily accessible resources, which renders stretch goals primarily distractive and harmful. Finally, the traditional theories imply that radical or disruptive innovations cannot be achieved via local research and local resources (Laursen \& Salter, 2006; Laursen, 2012; Rosenkopf \& Nerkar, 2001). However, bricolage-related activities, such as challenging the current institutional assumptions, can facilitate the creation of radical or disruptive innovations if the current resources are applied in some novel patterns (Baker \& Nelson, 2005).

In addition, the notion of exploratory bricolage suggests the way of using local resources in novel way. This is based on the fact that radical or disruptive innovations can be achieved only by breaking and transforming the formal rules and informal norms that are built upon the previous institutional assumptions. The insight of exploratory bricolage is that innovators can conduct radical or disruptive innovations by re-examining the taken-for-granted assumptions (Kaplan \& Vakili, 2015).

In particular, stretch goals can serve as salient enablers for bricolage. Even though exploratory bricolage and radical innovation are always hard to achieve, and even harder for late-coming firms from the emerging economies, unexpected outcomes could be achieved in the light of stretch goal, which may guide such firms to the final realization of bricolage. Due to the path-dependence nature of technological trajectory, economists find that it is difficult 
for the late-coming firms to challenge the early-moving firms in terms of technological innovations (Mueller, 1997; Nelson, 1990). Because technology development is restrained by path dependence (Mahoney, 2000), the late-coming firms could be locked for a long time in a lower and less competitive position. Advancement in information technology also makes it harder to achieve radical innovations by following the same path of the first-movers. Given this situation, radical innovation is the only way for the latecomers to surpass the first-movers. Due to the difficulties involved in the innovation process, perhaps only those latecomers with strong stretch goals can push themselves hard enough to adopt radically different patterns for their disruptive innovations.

Radical or disruptive innovation tends to be highly difficult to achieve, especially for the latecomers, even though some latecomers may have potential competitive advantages; so it would be misguided if the latecomers adopt the well-known paths of successful first-movers. In this sense, we argue that stretch goal may function as a driving force for radical innovation. From the perspective of behavioral theory of the firm (Cyert \& March, 1963), organizational search is always triggered by existing problems. When the traditional solutions to such problems fail, managers can be forced to engage in some innovative activities so as to achieve radical or disruptive innovations as novel solutions to such problems. Hence, pursuing a stretch goal can serve as a salient trigger for exploratory bricolage.

\section{Composition-Based View}

The Chinese style or pattern of innovation is argued to be unique in several aspects, and one of them is highlighted as a compositional approach. The compositional approach, coined as "composition-based view" (CBV), is proposed to explain how firms with insufficient resources and competencies can create competitive advantages (Luo \& Child, 2015). CBV 
provides some interesting insights into the question about how some firms with ordinary resources can generate extraordinary results by applying their unique integrating capabilities to their own ordinary resources and even others' ordinary resources to develop products with good price-value ratios to better meet the special needs of the mass-market consumers in emerging economies (Luo \& Child, 2015). However, we can go one step further by positing that entrepreneurial bricolage can serve as not only the core mechanism for CBV, but also something new beyond CBV by differentiating between three sub-patterns: (1) turning normal or ordinary resources (i.e., regular resources available via market exchange at fair prices) into extraordinary resources (i.e., VRIN resources or core competences for competitive advantages); (2) turning subnormal resources (i.e., irregular resources with controversial values or services, even though available via market exchange at distorted prices) into ordinary and/or extraordinary resources, and (3) turning even seemingly valueless non-resources (i.e., conventionally assumed valueless as measured by functional service or market value due to its public-good nature) into various types of valuable resources (i.e., subnormal, ordinary, and extraordinary or VRIN resources). In general terms, the first sub-pattern is consistent with CBV, but the second and third sub-patterns extend beyond CBV toward our notion of exploratory bricolage.

\section{Research Methodology}

We employ a case study approach to investigate how companies with severe resource constraints achieve stretch goals via ingenious methods. Case study is a useful method for theory building (Eisenhardt \& Graebner, 2007). Adopting the case study approach is appropriate for us because the aim of this study is to develop a new concept of explorative 
bricolage. We choose three cases for data analysis. The multiple-case approach provides a stronger base for theory-building than the single-case approach (Yin, 1994), since it enables us to verify our arguments in different contexts and increases the robustness of our findings. Following the suggestions of Eisenhardt and Graebner (2007), we sampled three companies in different industries to enhance our research design.

We analyze three cases to explore the specific mechanisms at different stages of entrepreneurial bricolage, especially the creative type of entrepreneurial bricolage. The three cases are: Yuanjia Village, a rural community that has developed a booming tourist operation with little or no conventional resources available for tourism; ZBOM, how a kitchen-furniture manufacturer that has achieved its ambitious goal of super-fast growth; and Huawei, a telecommunication equipment supplier that has transformed from a small local player to a world-class global player within a short-period of three decades.

The first and third cases primarily rely on secondary data. It is possible to collect key information from public sources because these two cases, especially Huawai, were widely publicized in media. The published secondary data are more objective than interview data and enable us to conduct cross-checks using multiple sources. The information of Yuanjia Village was collected from the major news outlets and video records of the interviews of the village's leaders and managers. The information of Huawei was collected from the company's news articles, annual reports and books that were written by the company's senior consultant with the authorization from the company (Tian \& Wu, 2015). For the case of ZBOM, although the company is a listed firm, its process of bricolage was not discussed intensively in the public media. Since we had direct access, we interviewed the founder and top executives of the 
company. All the data were collected from Chinese sources.

\section{Case Studies}

\section{Case Study 1: Yuanjia Village}

Yuanjia Village, a tourist attraction without literally any tourism resources, is an ordinary village on the Guanzhong plain in Shaanxi Province. Before launching the tourism business, Yuanjia Village had only 62 households and 286 villagers. It is a small, poorly-endowed village that has few natural resources, much less those resources required for tourism.

In the 1980s, taking advantage of the flourishing development of township and village enterprises, Yuanjia Village temporarily had a grand occasion under the leadership of the old village chief Guo Yulu. However, in the new century, the village-run enterprises are in a dilemma with the adjustment of national industrial policies. At that time, there was not much difference between Yuanjia Village and China's tens of millions of common rural areas. Most young villagers went out the village to make a living, and the village became a veritable hollow village. To revive the countryside, Guo Zhanwu, son of the old village chief, returned to be the village head. However, it is undoubtedly difficult to start a secondary startup, and similar to most start-ups, Yuanjia (refers to the company of Yuanjia, hereinafter) was facing a serious shortage of resources.

Guo Zhanwu later recalls that what he wanted at that time was to help the villagers get rich again through tourism and establish a Century Village of Yuanjia. This idea seemed insipid, and challenging as well. As mentioned before, Yuanjia Village possessed no natural tourism resources on its own. Although only four kilometers away from Zhaoling, the mausoleum of Emperor Li Shimin of the Tang Dynasty, Yuanjia Village cannot be regarded as 
a particularly attractive attraction in the Guanzhong area where cultural relics and historic sites are all over the country. Moreover, Zhaoling is not in the village, and it is hard to directly rely on Zhaoling tourism to increase the incomes of Yuanjia villagers. Therefore, despite such a vision, the villagers, including the village leaders, did not know how to achieve it. Even more than 20 outside planning experts concluded that Yuanjia Village could not sustain itself on tourism. In a speech in 2016, Guo Zhanwu said frankly that even the planning experts invited at that time thought that Yuanjia Village should cheat the government for subsidies.

In the face of a conflict between sharp ambitious vision and the lack of resource, Guo Zhanwu led Yuanjia Village to a surprising counter-attack. After 2007, Yuanjia Village chose to develop folklore tourism as a starting point, breaking through the paradox of grand vision and the scarcity of resources. In order to achieve the goal of getting rich by developing tourism, the managers of Yuanjia Village exploited two apparent opportunities: fully tapping the local conditions and bold innovating.

In terms of utilizing local conditions, Yuanjia Village focused on old and rustic (original) ecology. The village management team believed that to succeed in rural areas, it was necessary to understand the rural areas and understand peasants, and this is the greatest advantage of Yuanjia's management team. Therefore, in the course of development, Yuanjia Village did not recklessly over-pursue the integration of new resources to set up new scenic spots. Instead, it showed itself the most primitive life of peasants in Guanzhong Plain and opened up a unique tourism model of an ancient town plus food and snacks for visitors. In order to exert the so-called "old-fashioned advantage," Yuanjia Village took the villagers as 
the main body and mobilized the villagers in an all-round way. All the villagers' clothing, language and housing were integrated into the scenic spots so as to make tourism more accessible.

In turn, Yuanjia Village firmly grasped new and advanced (fashionable) with regard to bold innovation. The concept of folk-custom tourism developed by the village management team is fundamentally different from the traditional tourism industry based on scenic spots. It can be said that they created a blue ocean market and the demand of experiencing the rural areas of the specific urban consumer groups has been seized. During the development of folk-custom tourism, the village management team flexibly applied novel Internet thinking, such as free entrance tickets, free rental of shops and the continuous introduction of faddish products or services so as to rapidly attract large numbers of passengers and thus to compete in the highly competitive tourist market. They quickly stood firmly as a latecomer. At the same time, the village management team paid close attention to the management of old and rustic folk activities with the management mode of new and advanced. For example, Yuanjia Village made a unified and reasonable plan for the snacks in the scenic area. While ensuring the variety and quality of snack varieties, it maintained the reasonableness of the competition among the snacks in the village and posted promises of quality assurance and various supporting activities everywhere, all reflecting the managers' unique understanding of new and advanced management thinking.

From 2007 to today, 10 years past, Yuanjia Village has successfully stepped out of the first step of Century Yuanjia Village. Today, Yuanjia Village has become a well-known tourist brand in Shaanxi Province and even the whole country. It has 586 merchants with an annual 
tourist arrival of 5 million and an annual output value of 280 million yuan. In the Golden Week of 2015, this hollow village, which does not have any natural tourism resources, received a daily average of 180,000 tourists, much higher than the 69,400 visitors of Terracotta Warriors and Horses, ranking the first place in the Golden Week in Shaanxi Province. Competing with more and more imitators, Yuanjia Village is undergoing a new transformation. Its Hanzhong Impression Experience Store has entered the center of Xi'an City, channeling new passenger flow for village enterprises.

\section{Case Study 2: ZBOM}

ZBOM is a kitchen supplies manufacturer. Before 2008, ZBOM looked like a small and affluent local company specializing in kitchen cabinet business. From its founding in 1998 until 2008, ZBOM dwelled on its headquarters in Anhui Province without any ambition of expanding to other places. Before it started its entry into the Nanjing market in 2003, ZBOM had never been to any other regions or cities in the past 10 years. However, in the wake of the financial turmoil in 2008 and the downturn in the real estate market, the growth of the cabinet industry had been restrained. Consumers had become cautious about spending on home improvement and were in a wait-and-see attitude. The bleak environment made ZBOM to feel the crisis. Surprisingly, this winter was not too cold, the company doubled its growth in this year with sales amount exceeding 1 billion. This result greatly increased the morale of the team and even led the company to sense opportunity of the industry: many companies are standing by and wait to see the changes in the industry. But ZBOM thought it is a good time to overtake the industry.

At the end of 2009, the company's regular strategic seminar held as scheduled. Fifty 
executives sat around and routinely planned a second year of development. During the team discussion, the managing vice president held the view that what is now considered impossible will be possible 10 years from now, positing: why should we limit ourselves to the immediate situation? ZBOM could, therefore, enlarge resources, make optimistic and imaginative ideas, and find ways to really create such an environment and conditions. "We do not know what happened", all the executives we interviewed recalled, "the annual goal planning quickly evolved into a daring dream for the next decade". The discussion got more exciting, the final outcome is a co-developed stretch goal: one billion in three years, ten billion in ten years.

Once the goal has been set, related strategic path needs to be determined. Because of their choosing of stretch goal, in the absence of ample resources, their basic strategic path also has to go beyond the conventional but find unique strategic path. This is also the need for bricolage, that is, giving full play to the undiscovered potential of existing resources or making full use of the resources of others. This is exactly what ZBOM chose to do. Specifically, the main feature of their ingenious strategy is to separate the existing self-service sales companies and completely release the potential that they have not previously achieved, thus to make them become the vanguard of the massive expansion of ZBOM. In addition, ZBOM is almost desperate to recruit dealers across the country to make use of other resources to fulfil rapid expansion. For example, one billion in three years means that ZBOM will have to build 1,000 dealership stores in 2010 to 2012. The goal was successfully completed in the first two years, after all, simply because it started from a small base. In 2011, ZBOM recruited 210 dealerships. In 2012, according to the plan of one thousand stores in three years, they had to complete the task of recruiting 400 companies. 
However, at that time, the industry's highest record of recruitment was just about 200! At the time, being driving into a corner, the person in charge of recruitment inadvertently got inspiration from colleagues and proposed the 520-attracting-dealer-strategy: open 25 attracting investment conferences and breakdown the target of attracting 400 dealership stores; five large investment conferences are expected to draw 40 investment stores for each, which is 200 in total; the remaining 20 small investment conferences will each sign 10 stores, which is 200 in total. Therefore, the stretch goal of 400 stores was achieved. However, at that time, the investment attraction team can only make one investment promotion meeting a month, only 12 meetings can be done throughout the year. How to make 25 promotion activities in a year? They again split the investment department team into two major groups: one is responsible for the areas in the North and the other in the South. The two small teams strived for the aim simultaneously. In 2012, organizational adjustment plus 520-strategy to layout the national market only three years, ZBOM signed more than 1,000 dealers across the country, quickly occupied the national market. It is noteworthy that the development of ZBOM slowed down after 2012 and it seems difficult to maintain the momentum of the previous crazy expansion due to the need for stable results after the expansion. It appears that it is difficult for ZBOM to achieve its stretch goal of 10 billion in 2019 unless the top management team can find new ways to realize the stretch goal of bricolage.

ZBOM is praised as a "black horse" in the industry thanks to its outstanding performance during the past few years. Inside ZBOM, they have their own self-deprecating explanation of a "black horse": a horse that is running during both day and night. No one is compelled to behave like this, but it is simply because they have a stretch goal. Since they agree with this 
goal, they must achieve it. ZBOM has a saying that "one is a hero if he or she succeeds, otherwise he or she is a loser." In fact, it is still inexact to say "success" because, according to staff from ZBOM, "the goal is not to be accomplished but to be surpassed." In other words, both the wolf spirit of a company and its bricolage approach are driven by stretch goals.

\section{Case Study 3: Huawei}

The success of Huawei in the international market is triggered by stretch goal, and Huawei's bricolage approach is in turn driven by that stretch goal. This is particularly evident in the early and mid-term development history of Huawei. Huawei wanted to occupy one-third of the market share in the global telecommunication industry: this is a dream goal of Zhengfei Ren, the founder of Huawei. This dream was ambitious that in the early days of Huawei, Ren was called a crazy man. The stretch goal of Huawei is derived from, on the one hand, the real persecution of long-term survival of the company, which is more obvious in the early and mid-term development of Huawei; and on the other hand, from Zhengfei Ren's grand ideal, which has been proved numerous times throughout the process of Huawei growth.

Under the guidance of this grand dream, Huawei successfully adopted ingenious strategies of market competition, many of which have obvious features that break the common competition paradigm. There are two specific examples that can illustrate how Huawei adopted explorative bricolage in pursuing their stretch goals. First, normally telecommunication companies need to focus on urban markets where there is stable demand. Such markets are dominated by big companies, which have good relationships with municipal telecommunications bureaus. Hence, the entry barrier of the telecommunication 
industry is very high, making survival itself a stretch goal for many small companies, such as Huawei in early 1990s. To overcome this challenge, Huawei developed user exchanges that have little to do with the telecommunications bureau and conducted a marketing strategy of rural areas encircling cities. A second case of explorative bricolage is the product of Single-RAN, which is a radio access network (RAN) technology that allows mobile telecommunication operators to support multiple mobile communication standards and wireless telephone services on a single unit. Traditionally, telecommunication companies only provided network technologies to support a single mobile communication standard. However, in 2008, Huawei observed that many customers, especially customers who come from developing countries with restrained financial resources often operate in multiple mobile communications standards but cannot afford multiple networks. The market leaders at that time, such as Cisco, ignored this market opportunity because their innovation departments were not close enough to the customers, especially those customers from developing countries. Huawei realized this opportunity and launched Single-RAN. The product helped the company to create a competitive advantage in these markets quickly, playing a very important role in Huawei's catch up of the western leading companies. In fact, Single-RAN did not employ very advanced technology. Huawei's success can be largely explained by its bricolage mindset_—a mindset that enables the company to challenge the institutional assumptions.

These ingenious ways of competition helped Huawei stand out in the competitive landscape. Obviously, the ingenious mechanisms of Huawei are specific strategic actions for its central dream of occupying one-third of the world market share. 


\section{Case Study Summary}

The three cases we discussed above illustrate how firms facing resources constraints can achieve extraordinary performance by setting and chasing a stretch goal. To achieve their stretch goals, these three firms not only worked very hard, but also adopted a shared approach: they all stayed in their existing business domains rather than rushing into new domains, and at the same time, they explored and figured out radically novel approaches to reuse their limited resources at hand. As a result, their successes were often unexpected. Our theory of exploratory bricolage provides a good explanation of such success stories concerning the unexpected or reverse entrepreneurship against the odds in the context of emerging economies. We summarize the three cases in Table 1.1.

[Insert Table 1.1. about here]

\section{Discussion and Conclusion}

In sum, we believe that the concept of exploratory bricolage provides important insights into the process where resource-constrained latecomers from the emerging economies, such as Huawei, ZBOM, and Yuanjia Village, can convert or transform stretch goals into radical innovations so as to catch up with and even surpass the first-movers from the advanced economies. We also note that implementing exploratory bricolage must be supported by a variety of managerial measures. Exploratory bricolage is essentially about using local resources to explore radically novel (thus nonlocal) solutions in the focal organization's current business domain. Given the fact that exploration and exploitation constitute one of the most salient organizational paradoxes (Smith \& Lewis, 2011), balancing explorative searches for nonlocal solutions and exploitative searches for local resources is highly challenging because these two search behaviors require incompatible routines, organizational processes, 
and cognitive frames (Andriopoulos \& Lewis, 2009; Smith \& Lewis, 2011). Hence, one of the most important antecedents to exploratory bricolage is the managers' paradoxical mindset, which enables them to embrace the opposite elements as a holistic and dynamic balancing so as to engage in explorative and exploitative actions simultaneously (Li, 2012a, 2016).

Our study makes important theoretical contributions to the organizational learning and search literature (March, 1991; Laursen, 2012; Terjesen \& Patel, 2017). Different from traditional view of innovation, which emphasizes the importance of being creative by nonlocal search (Ahuja \& Lampert, 2001; Rosenkopf \& Nerkar, 2001), but in line with the recent finding of Kaplan and Vakili (2015) and Mastrogiorgio and Gilsing (2016), our theory highlights the importance of local search for nonlocal innovation. Obviously, conducting innovation through nonlocal search is much easier than conducting innovation via local search, because local search often relies more on redundant knowledge elements, but nonlocal search introduces new knowledge elements to the focal organization.

However, nonlocal search has two important limitations. First, in nonlocal search, because the focal organization must enter into an unfamiliar domain, it is difficult to develop in-depth, domain-specific knowledge. Second, search into distant knowledge domains tends to be costly (Ahuja \& Lampert, 2001), and small and young organizations with constrained resources may not be able to afford such cost. Local search, on the other hand, requires fewer supporting resources, but deeper domain-specific understanding, so it requires the focal organization to come up with more creative or novel approaches to recombining redundant and familiar resources. Thus, the balance between local search and nonlocal search is an important puzzle in the innovation and organizational learning literature (Gupta, Smith, \& 
Shalley, 2006; Lavie, Stettner, \& Tushman, 2010). We propose a new way of balancing these two search strategies and argue that firms can use local resource to explore nonlocal solutions. By looking at these three cases, we illustrate the usefulness of our approach in analyzing cases of latecomers with a stretch goal and severe resource constraints.

The core component of exploratory bricolage is creativity. We believe that exploratory bricolage, which is based on local search for nonlocal innovation, requires a higher level of creativity than traditional breakthrough innovation based on nonlocal search. Following studies may make a connection between explorative bricolage and the creativity literature (Anderson, Potočnik, \& Zhou, 2014). Specifically, in the Chinese context, radical creativity is closely related to the concept of " $W u$ ", which refers to intuitive imagination for insight via metaphor (Li, 2012b, 2014). The research on " $W u$ " and our concept of exploratory bricolage can be integrated in the future.

Future research can also investigate the organizational enablers of exploratory bricolage. Conducting exploratory bricolage needs to be supported by organizational flexibility and agility. In order to break its path-dependence, the focal organization needs to be agile so as to respond to the changing environment by updating assumptions, routines, and organizational processes (Sambamurthy, Bharadwaj, \& Grover, 2003). Consequently, organizations must have strong dynamic capabilities (Teece, 2007; Teece, Pisano \& Shuen, 1997) to effectively engage in exploratory bricolage. Accordingly, organizational structure, governance structure, reward systems, and employee training programs need to be carefully designed to facilitate the development of dynamic capability and organizational learning.

In addition, exploratory bricolage requires strong leadership, like in our three cases. How 
to motivate human talents and coordinate their activities is one of the most critical issues of implementing exploratory bricolage. Leaders play a central role in motivating and guiding employees of the whole organization for the pursuit of a stretch goal and also exploratory bricolage. As we can see in the three cases discussed above, all of them faced frustrations when proposed plans failed to deliver expected performance. If such stress and frustrations cannot be managed well, such organizations would fall into a vicious, downward spiral, and the negative effects of having a stretch goal would occur (Sitkin et al., 2011). A strong leader can serve as a motivator, a role model and a coordinator, so such a leader helps an organization to commit itself to a stretch goal and maintain a strong motivation during challenging times. In this sense, only a strong leader, who often has features such as transformational leadership and anti-fragility, can manage exploratory bricolage in an effective pattern.

Last but not the least, our study provides important practical implications to the entrepreneurs and managers of late-coming companies. Although more and more recent studies attempt to understand how these firms can catch-up in the technological race and compete with first movers and incumbents (Luo \& Child, 2015; Miao et al., 2018), we still need more theories to explain this important puzzle. By incorporating the literature of stretch goal, bricolage, and organizational search, our study offers a unique explanation of this puzzle and a useful guideline to practitioner.

\section{References}

Ahuja, G., \& Morris Lampert, C. (2001). Entrepreneurship in the large corporation: A longitudinal study of how established firms create breakthrough inventions. Strategic 
Management Journal, 22(6-7):521-543.

Anderson, N., Potočnik, K., \& Zhou, J. (2014). Innovation and creativity in organizations: A state-of-the-science review, prospective commentary, and guiding framework. Journal of Management, 40(5), 1297-1333.

Andriopoulos, C., \& Lewis, M.W. (2009). Exploitation-exploration tensions and organizational ambidexterity: Managing paradoxes of innovation. Organization Science, 20(4), 696-717.

Baker, T., \& Nelson, R. E. (2005). Creating something from nothing: Resource construction through entrepreneurial bricolage. Administrative science quarterly, 50(3):329-366.

Baker, T., Miner, A., \& Eesley, D. (2003). Improvising firms: Bricolage, account giving and improvisational competency in the founding process. Research Policy, 32 (2): 255-76.

Barney, J. (1991). Firm resources and sustained competitive advantage. Journal of management, 17(1): 99-120.

Barney, J. B. (2001). Is the resource-based "view" a useful perspective for strategic management research? Yes. Academy of Management Review, 26(1): 41-56.

Cyert, R. M., \& March, J. G. (1963). A behavioral theory of the firm. Englewood Cliffs, NJ: Prentice Hall.

Eisenhardt, E., \& Graebner, G. (2007). Theory Building from Cases: Opportunities and Challenges Academy of Management Journal, 50(1): 25-32.

Fisher, G. (2012). Effectuation, causation, and bricolage: A behavioral comparison of emerging theories in entrepreneurship research. Entrepreneurship Theory and Practice, 36(5):1019-1051.

Fisher, G. 2012. Effectuation, causation, and bricolage: a behavioral comparison of emerging theories in entrepreneurship research, Entrepreneurship Theory and Practice, 36 (5): 1019-1051.

Garud, R., \& Karnøe, P. (2003). Bricolage versus breakthrough: distributed and embedded agency in technology entrepreneurship. Research Policy, 32(2):277-300.

Gary, S., Yang, M., Yetton, P., \& Sterman, J. (2017). Stretch Goals and the Distribution of Organizational Performance. Organization Science, 28(3):395-410.

Guo, H., Su, Z., \& Ahlstrom, D. (2016). Business model innovation: The effects of exploratory orientation, opportunity recognition, and entrepreneurial bricolage in an emerging economy. Asia Pacific Journal of Management, 33(2):533-549.

Gupta, A.K., Smith, K., \& Shalley, C.E. (2006). The interplay between exploration and exploitation. Academy of Management Journal, 49(4): 693-706.

Gurca, A., \& Ravishankar, M. (2016). A bricolage perspective on technological innovation in emerging markets. IEEE Transactions on Engineering Management, 63(1):53-66.

Jung, H., \& Lee, J. (2016). The quest for originality: A new typology of knowledge search and breakthrough inventions. Academy of Management Journal, 59(5):1725-1753.

Kaish, S., \& Gilad, B. (1991). Characteristics of opportunities search of entrepreneurs versus executives: Sources, interests, general alertness. Journal of Business venturing, 6(1):45-61.

Kaplan, S., \& Vakili, K. (2015). The double- edged sword of recombination in breakthrough innovation. Strategic Management Journal, 36(10):1435-1457.

Katila, R., \& Shane, S. (2005). When are new firms more innovative than established firms? Academy of Management Journal, 48(5):814-829. 
Laursen, K., \& Salter, A.J., (2006). Open for innovation: the role of openness in explaining innovative performance among UK manufacturing firms. Strategic Management Journal, 27:131-150.

Laursen, K., (2012). Keep searching and you'll find: what do we know about variety creation through firms' search activities for innovation? Industrial and Corporate Change, 21:11811220 .

Lavie, D., Stettner, U., \& Tushman, M., (2010). Exploration and Exploitation Within and Across Organizations. The Academy of Management Annals, 4(1):109-155.

Lee, K., \& Lim, C. 2001. Technological regimes, catching-up and leapfrogging: Findings from the Korean industries. Research Policy, 30(3): 459-483.

Levinthal, D. A., \& March, J. G. (1993). The myopia of learning. Strategic Management Journal, 14(S2):95-112.

Li, P. P. (2012a). Toward an integrative framework of indigenous research: The geocentric implications of Yin-Yang balance. Asia Pacific Journal of Management, 29(4): 849-872. Li, P. P. (2012b). Exploring the unique roles of trust and play in private creativity: From the complexity-ambiguity-metaphor link to the trust-play-creativity link. Journal of Trust Research, 2: 71-97.

Li, P. P. (2014). Toward the geocentric framework of intuition: The Yin-Yang Balancing between the Eastern and Western perspectives on intuition. Handbook of intuition research methodology (Edward Elgar Publishers), Sinclair, M. (Ed.), Chapter 3: 28-41.

Li, P. P. (2016). Global implications of the indigenous epistemological system from the East: How to apply Yin-Yang balancing to paradox management. Cross Cultural \& Strategic Management, 23(1): 42-77.

Locke, E.A., \& Latham, G.P. (2013). New Developments in Goal Setting and Task Performance. London, Routledge.

Luo, Y., \& Child, J. (2015). A composition-based view of firm growth. Management and Organization Review, 11(3):379-411.

Mahoney, J. (2000). Path dependence in historical sociology. Theory and Society, 29(4):507-548.

Mastrogiorgio, M. \& Gilsing, V. (2016). Innovation through exaptation and its determinants: The role of technological complexity, analogy making \& patent scope. Research Policy, 45:1419-1435.

Miao, Y., Song, J., Lee, K., \& Jin, C. (2018). Technological catch-up by East Asian firms: Trends, issues, and future research agenda. Asia Pacific Journal of Management, 35(3): 639-669.

Miron-Spektor, E., \& Beenen, G. (2015). Motivating creativity: The effects of sequential and simultaneous learning and performance achievement goals on product novelty and usefulness. Organizational Behavior and Human Decision Processes, 127 (2015): 53-65.

Nelson, R. (1990). US technological leadership: Where did it come from and where did it go? Research Policy, 19(2): 117-132.

Rosenkopf, L., \& Almeida, P. (2003). Overcoming Local Search through Alliances and Mobility. Management Science, 49(6): 751-766.

Rosenkopf, L., \& Nerkar, A. (2001). Beyond local search: boundary- spanning, exploration, and impact in the optical disk industry. Strategic Management Journal, 22(4):287-306. 
Salunke, S., Weerawardena, J., \& McColl-Kennedy, J. R. (2013). Competing through service innovation: The role of bricolage and entrepreneurship in project-oriented firms. Journal of Business Research, 66(8):1085-1097.

Sambamurthy, V., Bharadwaj, A., and Grover, V. (2003). Shaping agility through digital options: reconceptualizing the role of information technology in contemporary firms. MIS Quarterly, 27(2), 237-263.

Sarasvathy, S. (2001). Causation and effectuation: toward a theoretical shift from economic inevitability to entrepreneurial contingency. Academy of Management Review, 26 (2): 243-263.

Sarasvathy, S. (2008). Effectuation--Elements of Entrepreneurial Expertise. Edward Elgar, Cheltenham.

Senyard, J., Baker, T., Steffens, P., \& Davidsson, P. (2014). Bricolage as a path to innovativeness for resource-constrained new firms. Journal of Product Innovation Management, 31(2):211-230.

Sitkin, S. B., See, K. E., Miller, C. C., Lawless, M. W., \& Carton, A. M. (2011). The paradox of stretch goals: Organizations in pursuit of the seemingly impossible. Academy of Management Review, 36(3):544-566.

Smith, W. K., \& Lewis, M. W. (2011). Toward a theory of paradox: A dynamic equilibrium model of organizing. Academy of Management Review, 36(2):381-403.

Teece, D. J., Pisano, G., \& Shuen, A. (1997). Dynamic Capabilities and Strategic Management. Strategic Management Journal, 18(7):509-533.

Terjesen, S., \& Patel, P. (2017). In Search of Process Innovations: The Role of Search Depth, Search Breadth, and the Industry Environment. Journal of Management, 43(5): 1421-1446. Terziovski, M. (2010). Innovation practice and its performance implications in small and medium enterprises (SMEs) in the manufacturing sector: a resource- based view. Strategic Management Journal, 31(8):892-902.

Tian, T., \& Wu, X. (2015). Will Huawei be the next one to collapse? China Citic Press, Beijing, China. (in Chinese)

Welter, C., Mauer, R., \& Wuebker, R. J. (2016). Bridging behavioral models and theoretical concepts: effectuation and bricolage in the opportunity creation framework. Strategic

Entrepreneurship Journal, 10(1):5-20.

Wu, L., Liu, H., \& Zhang, J. (2017). Bricolage effects on new-product development speed and creativity: The moderating role of technological turbulence. Journal of Business

Research, 70:127-135.

Wu, X., Ma, R., \& Shi, Y. (2010). How do Latecomer Firms Capture Value from Disruptive Technologies? A Secondary Business-Model Innovation Perspective. IEEE Transactions on Engineering Management, 57 (1):51-62.

Yin, R. K. (1994). Case study research: Design and methods (2nd ed.). Newbury Park, CA: Sage. 
Table 1.1. Summary of Three Cases

\begin{tabular}{|c|c|c|c|c|c|}
\hline Case Study & \begin{tabular}{|l} 
Time \\
period for \\
bricolage
\end{tabular} & $\begin{array}{l}\text { Resource } \\
\text { status before } \\
\text { bricolage }\end{array}$ & Stretch goal & Explorative bricolage & Results of bricolage \\
\hline $\begin{array}{l}\text { Case } 1 \\
\text { The company of } \\
\text { Yuanjia Village } \\
\text { (A small-scale } \\
\text { collective enterprise) }\end{array}$ & \begin{tabular}{|l} 
Transition \\
period \\
(around \\
2007 )
\end{tabular} & $\begin{array}{l}\text { Lack of natural } \\
\text { tourism } \\
\text { resources } \\
\text { Lack of } \\
\text { financial } \\
\text { resources }\end{array}$ & $\begin{array}{l}\text { Wish to develop } \\
\text { tourism with no } \\
\text { tourism resources } \\
\text { Labeled as "fraud" } \\
\text { of national subsidy } \\
\text { by tourism experts }\end{array}$ & $\begin{array}{l}\text { Develop "peasant-household tourism" and } \\
\text { create a new tourism mode of "Folklore } \\
\text { Tourism"; } \\
\text { (challenge the assumption that natural } \\
\text { tourism resources are necessary for } \\
\text { developing a tourism industry; reuse } \\
\text { peasant-households as resources for } \\
\text { tourism) }\end{array}$ & $\begin{array}{l}\text { Became the most } \\
\text { popular destination } \\
\text { for tourists } \\
\text { Became the } \\
\text { most-attractive tourist } \\
\text { attraction in Shanxi } \\
\text { province during the } \\
\text { National holiday }\end{array}$ \\
\hline $\begin{array}{l}\text { Case } 2 \\
\text { ZBOM } \\
\text { (a small-scale } \\
\text { kitchen supplies } \\
\text { manufacturer) }\end{array}$ & $\begin{array}{l}\text { 2009/12- } \\
\text { 2012/12 }\end{array}$ & $\begin{array}{l}\text { Sales exceed } \\
100 \text { million } \\
\text { RMB; }\end{array}$ & $\begin{array}{l}\text { Sales reach } 1 \\
\text { billion in three } \\
\text { years } \\
\text { Ranked No. } 3 \text { in the } \\
\text { field [No. } 1 \text { has the } \\
\text { sales of up to } 300 \\
\text { million in 2008] }\end{array}$ & $\begin{array}{l}\text { 520-attracting-dealer-strategy: open } 25 \\
\text { attracting investment conferences, } \\
\text { breakdown the target of attracting } 400 \\
\text { dealership stores } \\
\text { (challenge the institutional assumption } \\
\text { that a kitchen supplies business is } \\
\text { operated in a self-operated business } \\
\text { model) }\end{array}$ & $\begin{array}{l}\text { Entered the top three } \\
\text { domestic company in } \\
\text { the industry } \\
\text { Achieved the goal of } \\
1 \text { billion sales that } \\
\text { increased by } 10 \text { times } \\
\text { in } 3 \text { years. }\end{array}$ \\
\hline
\end{tabular}




\begin{tabular}{|l|l|l|l|l|l|}
\hline Case 3 & $\begin{array}{l}\text { The 1990s } \\
\text { to the } \\
\text { mid-2000s }\end{array}$ & $\begin{array}{l}\text { Being a } \\
\text { latecomer in the } \\
\text { technological } \\
\text { race with } \\
\text { international } \\
\text { competitors } \\
\text { medium-sized } \\
\text { telecommunication } \\
\text { company which does } \\
\text { not have a } \\
\text { competitive } \\
\text { advantage in the } \\
\text { international market) }\end{array}$ & $\begin{array}{l}\text { Top three in the } \\
\text { world }\end{array}$ & $\begin{array}{l}\text { Marketing strategy of rural areas } \\
\text { encircling cities }\end{array}$ & $\begin{array}{l}\text { Caught up the western } \\
\text { leading companies } \\
\text { (challenge the assumption that major } \\
\text { customer of the industry is in the city) }\end{array}$ \\
\hline
\end{tabular}

